IRSH 62 (2017), Special Issue, pp. $245^{-269}$ doi: I0.10 I $7 /$ So0 20859017000578 (C) 20 I 8 Internationaal Instituut voor Sociale Geschiedenis

\title{
Looking at the Southern Cone: American Trade Unionism in the Cold War Military Dictatorships of Brazil and Argentina
}

\author{
LARISSA ROSA CORREA \\ Departamento de História \\ Pontifícia Universidade Católica of Rio de Janeiro \\ R. Marquês de São Vicente, 225 - Gávea \\ Rio de Janeiro - RJ, 22430-06o, Brazil \\ E-mail: larissa_correa@puc-rio.br
}

\begin{abstract}
This article analyzes the AFL-CIO's anticommunist international policy in the period just before and after the overthrow of democratic regimes in Brazil (1964) and Argentina (1966-I976). It focuses on the activities of the American Institute for Free Labor Development (AIFLD), a labor organization closely associated with US foreign policy interests. By highlighting similarities, differences, and direct connections between US labor activities in these two South American countries, I argue that Brazil's I964 coup and subsequent dictatorship were key experiences for US trade unionists as they formulated an AFL-CIO labor policy for Argentina and the rest of the Southern Cone.
\end{abstract}

In May 20I6, Brazil was approaching the climax of its worst political crisis in half a century. The month before, the lower house of Congress had voted to impeach center-left President Dilma Rousseff on trumped-up charges, and by May a judicial-parliamentary coup was in full swing. ${ }^{\mathrm{I}}$ Like many other foreign leftist organizations, the AFL-CIO came out strongly against the impeachment. In an online statement, the union drew comparisons to Brazil's 1964 coup, identifying it as a civilian-military movement headed by conservative elites to overthrow President João Goulart. The result of this intervention, they stated, was the death, disappearance, or torture of hundreds of the regime's opponents. Now, more than fifty years later, these same elites had engineered a movement to remove another

I. Those who consider Rousseff's impeachment a coup still do not agree on the proper terminology. Some have called it a judicial-media coup, because it enjoyed the support of the country's major media outlets. For Rousseff's opponents, her impeachment was both legal and democratic. 
president, Brazil's first female head of state. ${ }^{2}$ Yet, amidst all the parallels the AFL-CIO drew with I964, they remained conspicuously silent about their own reaction to the coup that had overthrown Goulart. For in 1964, the union had sided with the very elites whom they now condemned, which marked the beginning of over a decade of support for military coups and right-wing dictatorships across Latin America.

Throughout the I960s and I970s, the AFL-CIO invested in union education programs and social development with the aim of promoting "free unionism" in Latin America. In the Southern Cone, the main targets for American trade unionism were Argentina, Brazil, and Chile, seen as strategic countries to contain the advance of communism. ${ }^{3}$ In each country, they intensified their activities immediately preceding and following the military coups: Brazil in 1964, Argentina in 1966 and 1976, and Chile in 1973. This article compares the approaches of American unionism in Brazil and Argentina. It is part of a larger, ongoing project that compares the activities of American trade unionism in all three countries. ${ }^{4}$ More broadly still, it also has implications for the way scholars understand the role of the United States in other Latin American countries. The first part of the article offers a general overview of the principles, goals, and characteristics of the American Institute for Free Labor Development (AIFLD), the AFL-CIO's main representative in Latin America. It will then analyze in more detail the AIFLD's role in Brazil in order to offer some comparisons with the Argentine case.

My previous research on the AFL-CIO in Brazil in the I960s and I970s uncovered a series of diplomatic agreements and disagreements concerning the conflicts and alliances forged and thwarted between unionists and Brazilian and American political authorities. ${ }^{5}$ Using reports produced by the AFL-CIO, Brazilian and international union publications, analyses written by diplomats at the American embassy, interviews, police records, and newspapers, I traced Brazilian-American labor relations until I979, when Brazil's military dictatorship entered a phase of gradual democratic opening called abertura. This previous research serves as a point of departure from which to draw comparisons with Argentina, thereby offering a deeper

2. Brian Finnegan, "AFL-CIO Stands with Brazilian Workers and Democracy", 24 May 20I6, http://www.aflcio.org/Blog/Global-Action/AFL-CIO-Stands-with-Brazilian-Workersand-Democracy; last accessed is October 2017.

3. For reasons of convenience, "American" is used here as a short-hand for "US-American", although it is clear that "America" is a large continent made up of thirty-five nation states (and a number of dependent territories). Similarly, "Southern Cone" is used in this article including the whole of Brazil although most definitions only see some of the southern Brazilian states as part of this macro-region. 4. The project, financed by Pontifícia Universidade Católica of Rio de Janeiro, is titled "Relações sindicais Estados Unidos e América Latina. A atuação do sindicalismo norte-americano nas ditaduras militares do Brasil, Argentina e Chile".

5. See Larissa Rosa Corrêa, Disseram que voltei americanizado. Relações sindicais Brasil e Estados Unidos na ditadura militar (Campinas, 2017). 
understanding of both the similarities and differences between these national contexts, and the general orientations of AFL-CIO policy in the region.

In order to create a concrete basis for comparison, I focus here on three questions: First, which Brazilian and Argentinian unions were involved in the AFL-CIO's international education program and what was the character of these unions? Second, what sorts of social projects did the American union finance and how many students were involved in the union's educational programs, and what were the contents of their training courses like? Third, what sorts of other activities did the AIFLD spearhead? Answering these three questions enables us to understand the reach and possible impacts of programs intended to establish "free" trade unionism in Argentina and Brazil.

As this article will show, the Americans' experiences after Brazil's I964 coup to a great extent influenced the AFL-CIO's "free and democratic" activities in Argentina in 1966 and 1976, as well as in Chile in 1973. By the time the AIFLD expanded its operations in Argentina with an office in Córdoba in I968, American union leadership not only knew about the Brazilian generals' political and economic project and the repression they had unleashed against activists and workers; they also had developed a specific stance towards regimes of this kind: tacitly accepting them in their anti-communist thrust, the American representatives hoped to influence the officers and civilians that ran the regimes in terms of what they saw as an appropriate labor policy. ${ }^{6}$

It is not possible to understand the policies of American unions toward Latin America without considering the specific national political contexts, permeated, on the one hand, by the ideological struggle between the countries of the, as it was called then, First and Second Worlds during the Cold War, and, on the other, by the different types of political-economic projects carried out by the dictatorial regimes. As Victoria Basualdo observes, "interpretations of the Cold War that focus solely on the two sides of the ideological dispute are neither sufficient nor useful for understanding the Latin American dynamic." To conduct a transnational and comparative analysis about the impact of the Cold War on Latin America, it is essential to be aware of the interests and internal logics of the countries that were targeted by international bilateral politics, not simply the positions they took in the central conflict. ${ }^{7}$

Moreover, as Barbara Weinstein points out, "much of the literature about the relations between the US and Latin America has been written from the

6. The Brazilian military started immediately after the coup to imprison and torture those it considered "enemies of the country". These violations were denounced early on by the journalist and future federal deputy Márcio Moreira Alves in Tortura e torturados (Rio de Janeiro, 1966). Meanwhile, the Brazilian press, still free of military censorship, condemned the abuses committed by the regime's political police already shortly after the coup. The first references to torture appeared in Correio da Manhã, 7 April 1964.

7. Victoria Basualdo, "El movimiento sindical argentino y sus relaciones internacionales. Una contribución sobre la presencia de la CIOSL y la ORIT en la Argentina desde fines de los ' 40 hasta comienzos de los' 80", Revista Mundos do Trabalho, 5:10 (2013), pp. I99-2 I9, 200. 
top down, that is, from the perspective of the US, with Latin Americans generally portrayed as passive or unlucky victims of US policy." ${ }^{8}$ Similarly, Hal Brands argues, "[m]ost scholarship by US diplomatic historians focuses on the view from Washington, as is the case with even the best accounts of US-Latin American affairs." In contrast, Brands has pointed to the diversity of meanings that the ideological discourses produced by the global powers during the Cold War had in Latin American countries. ${ }^{9}$ Recent scholarship has gone beyond the conventional field of diplomatic studies of the Cold War, as researchers have begun to offer a broader and less Manichean perspective on US-Latin American relations. Their multidimensional, transnational perspectives have decentered the US and incorporated a variety of national and regional actors, including governments, political parties, and an assortment of left- and right-wing movements. In so doing, they have uncovered a series of overlapping conflicts in a tangled web of interests both political and economic, regional and national, all competing with the interests of the global superpowers. ${ }^{10}$

To analyze relations between the US, Brazil, and Argentina during the Cold War, it is also necessary to take into account the nationaldevelopmentalist projects of industrial modernization orchestrated by Brazil and Argentina's mid-century populist leaders, Getúlio Vargas (1930-1945) and Juan Perón (1946-1955). The search for a "third way" that could escape the stark options offered by the capitalist-communist binary through emphasizing national interests might be key for a better understanding of the dynamics of Cold War conflicts between the US and Latin America. Whenever political, economic, and social tensions ran high, nationalism and antiAmericanism served as a point of convergence for union leaders, workers, political authorities, and even domestic business leaders.

To a great extent, this "third way" was, amongst other references, the result of the dissemination of the ideals of Catholic social doctrine, by this time well established in the Latin American labor movement, which caused many union leaders and rank and file workers to reject or at least mistrust the "free" unionism so touted by the Americans. In that regard, both catholic labor organizations and those of the non-religious left shared common ground. American authorities and union leaders certainly knew

8. Barbara Weinstein, "Foreword", in Carla Simone Rodeghero, Capitulos da Guerra Fria. O anticomunismo brasileiro sob o olhar norte- americano (Porto Alegre, 2007), [unpaginated]. A recent example for such US-centered perspectives is Kim Scipes, AFL-CIO's Secret War against Developing Country Workers: Solidarity or Sabotage? (Lanham, MD, 2010).

9. Hal Brands, Latin America's Cold War (Cambridge, MA, 2010), p. 2.

Io. The body of literature using such extended perspectives on the Cold War in Latin America is growing rapidly. See, for example, Tom Long, Latin America Confronts the United States: Asymmetry and Influence (Cambridge, 20I5); Tanya Harmer, Allende's Chile and the InterAmerican Cold War (Chapel Hill, NC, 201 I); Jeffrey Taffet, Foreign Aid as Foreign Policy: The Alliance of Progress in Latin America (New York, 2007). 
that nationalism and anti-Americanism created serious obstacles for them in the Southern Cone. It was not by happenstance that American authorities went out of their way to clarify for Latin Americans that John F. Kennedy's Alliance for Progress did not constitute US intervention, but rather interAmerican cooperation. Typically for its time, a Brazilian worker stated categorically in an interview for a major national newspaper, "Neither Prague, nor Geneva", pointing to the seat of the "Eastern" World Federation of Trade Unions (WFTU) in Prague, yet mistakenly associating "free unionism" with "Geneva" (the seat of the UN-affiliated International Labour Organization), while the "Western" International Confederation of Free Trade Unions (1919-2006) had its headquarters in Brussels. In any case, the worker added wittily, “Couldn't it be Prague, Geneva, or Brasília?” I

\section{FOUNDING AND EARLY YEARS OF THE AIFLD}

In I96I, after the fiasco of the Bay of Pigs invasion, President John F. Kennedy became convinced of the importance of trade unions as a key factor in economic and social development, as well as a constraint on the influence of communism and nationalism in Latin America. Thus, the Kennedy administration decided to invest in a regional labor education program under the supervision of the AFL-CIO. The same year, still in the shadow of the 1959 Cuban Revolution, Kennedy launched the Alliance for Progress in Latin America. It aimed to improve economic, social, and political conditions in the region over a ten-year period with a heavy infusion of US aid. ${ }^{\mathrm{I2}}$

For the US government, the situation in Brazil in the early I960s was dangerous and worrying. A political atmosphere of dissatisfaction, they argued, made Latin America in general an "easy target" for communism. Due in no small measure to their mistreatment at the hands of the region's elites, Latin America's working class was a potential revolutionary force. To stave off this frightening possibility, the American government felt an urgent need to export the US model of capitalist democracy, seen as the antidote to both the oligarchic and often state-directed capitalism of Latin

I I. After participating in an event organized by the National Confederation of Communication and Advertising Workers (Confederação Nacional dos Trabalhadores de Comunicação e Publicidade) the interviewed union activists José Mauro Ribeiro Lobo asserted that the relation between his union and the International Federation of Petroleum and Chemical Workers caused distrust to him, adding that a genuinely Brazilian labour movement needed to be built, in which "the workers are freed from the illussion of either the right or the left". Interview extracts are cited from a parliamentary commission report about "foreign entities" in Brazil: Câmara dos Deputados, "Relatório Final da Comissão Parlamentar de Inquérito sobre as entidades estrangeiras no Brasil", Diário do Congresso Nacional, seção I, 28 de agosto de 1970, 102.

I 2. The Alliance for Progress provided technical and financial aid targeted at primary education, agrarian reform, healthcare, housing, currency stabilization, and various cooperative programs. For a general assessment see the contributions to: John E. Dreier (ed.), The Alliance for Progress: Problems and Perspectives (New York, 1987). 
America's elites and the totalitarian socialism of global communism. They thus sought to shape a new Latin American working class that would buy into the US model of labor relations and workplace regulation. This so-called free and democratic trade unionism was also expected to lead to a better relationship between native workers and foreign employers, since Latin America was being targeted by US corporations eager to expand their business. ${ }^{\mathrm{I}}$

In this political context, the Alliance for Progress boosted the AFL-CIO's labor education program for Latin America. ${ }^{14}$ US policymakers also saw Brazil as a key regional power that should play a vital role in achieving the Alliance's goals. ${ }^{\text {Is }}$ Until the early i960s, the AFL (with the support of the $\mathrm{CIO}$ ) already had promoted sporadic visits of Brazilian trade unionists to the United States and vice versa. Furthermore, some exchange activities were undertaken in cooperation with the International Confederation of Free Trade Unions (ICFTU) and the Interamerican Regional Organization of Workers (ORIT). ${ }^{16}$ The new policy, however, led to a dramatic expansion of the reach of American trade unionism in the region. In 1962, the AFL-CIO founded the American Institute for Free Labor Development (AIFLD) pooling substantial financial means from different sources. ${ }^{17}$ Seeking to establish ties with Latin American trade unionists, the AIFLD soon started to finance exchange programs and regular visits to the United States, amongst other activities. ${ }^{18}$ In the words of the AFL-CIO president George Meany, "[t]he AFL-CIO maintains the AIFLD to bring the example of the US trade union movement to workers in Latin America and the Caribbean." "I In practice, these actions counted on

I3. This position, including the noteworthy critique of the Latin American elites, was staked out for instance, in Robert H. Dockery, Survey of the Alliance for Progress: Labor Policies and Programs [A Study Prepared at the Request of the Subcommittee on American Republics Affairs and Committee on Foreign Relations of the United States Senate], (Washington, DC, I968), p. 6, available at http://http://pdf.usaid.gov/pdf_docs/pcaaa242.pdf; last accessed 30 November 2017. I4. Hobart A. Spalding Jr., "US and Latin American Labor: The Dynamics of Imperialist Control”, Latin American Perspectives, 3:I (1976), pp. 45-69, 52.

I 5. There is an extensive literature published during the I960s and I970s on social issues in Latin America. For a typical example see: John Gerassi, The Great Fear in Latin America (New York, 1963). I6. For an overview of the ORIT and the first contacts between the US labor confederations and Latin American trade unionists, see Robert J. Alexander, "Labor and Inter-American Relations", Annals of the American Academy of Political and Social Science, 334 (196I), pp. 4I-53.

17. Similar institutions were also founded for other world regions: The African-American Labor Center was created in 1964, followed by the Asian-American Free Labor Institute four years later. The latter focused on the Vietnamese labor movement. Beth Sims, Workers of the World Undermined: American Labor's Role in US Foreign Policy (Boston, MA, I992), p. 3.

I 8. Substantial documentation originating from AIFLD is available to researchers as part of the George Meany Memorial AFL-CIO Archive at the University of Maryland. For more details about the accessible source see: https://drive.google.com/file/d/oB 270iiodc9t9UE9zSXJXO W 5 EYik/view; last accessed is October 2017.

19. American Institute for Free Labor Development [hereafter, AIFLD], 1962-1972: A Decade of Worker to Worker Cooperation (Washington, DC, 1972), p. 2 I. 
the support of the most anti-communist and conservative sectors in the Latin-American trade union movement. The AIFLD over the years also established offices in Argentina, Chile, Uruguay, and Bolivia, along with other Latin American and Caribbean countries.

The AIFLD was sustained with means from different funders (which also changed according to its activities), including, American corporations, the AFL-CIO, and different US government agencies and initiatives, such as USAID, the Alliance for Progress, etc. ${ }^{20}$ The institute was a private, non-profit organization, led by Serafino Romualdi, an ardent anti-communist with a long relationship with conservative Brazilian trade unionists. ${ }^{2 \mathrm{I}}$ During the I940s and I950s, Romualdi had served as an official Latin American representative, first of the AFL, then of the AFL-CIO, tasked with forming alliances with local unionists and the authorities. He had been particularly active in Brazil and Argentina, where he had opposed the governments of Vargas, Perón, and later, João Goulart. His track record in both countries was highly controversial. Banned from entering Argentina by order of Perón, Romualdi had been constantly accused of attempting to interfere in the Argentine labor movement. ${ }^{22}$

Latin American trade unionists were invited to take part in an intensive three-month labor course at the Front Royal Institute in Virginia. The site could accommodate up to forty guests at a time. The Institute functioned like a boarding school, with the students spending all their time there, all expenses paid by the AIFLD. They were trained in leadership techniques, labor education, finance, history of the international labor movement, economics, statistics, English, and, most importantly, collective bargaining techniques. Later, these courses were moved to Loyola University in New Orleans and Georgetown University in Washington. ${ }^{23}$ All told, the Alliance for Progress oversaw the allocation of \$24 million to AIFLD and another institution, International Technical Assistance Corps of the Department of Labor (DOLITAC) ${ }^{24}$ to invest in the Latin American labor movement. ${ }^{25}$

20. Hundreds of US companies sponsored AIFLD activities in Latin America. This also manifested itself in AIFLD's governing bodies: In 1965, for instance, Charles M. Brinckerhoff (Anaconda Corporation), William Hinckley (United Corporation), Robert Hill (Merck and Company), Juan T. Trippe (Pan American World Airways), Henry Woodbridge (Tru-Temper Copper Corporation), and J. Peter Grace (W.R. Grace Corporation) were all members of the AIFLD Executive Board.

2 I. See his autobiographical account: Serafino Romualdi, Presidents and Peons: Recollections of a Labor Ambassador in Latin America (New York, 1967).

22. Ibid., p. 58 .

23. AIFLD, 1962-1972: A Decade of Worker to Worker Cooperation, p. 23.

24. In 1964, the Department of Labor initiated the International Technical Assistance Corps (DOLITAC), which was made up of US experts who served abroad helping foreign countries solve labor problems in a more technocratic vein, i.e. in terms of traning, intermediation, addressing labor market deficiencies, etc.

25. Dockery, Survey of the Alliance for Progress, p. Io. 
Soon after its foundation, the AIFLD began to work more closely with the Inter-American Regional Organization of Workers (ORIT). Founded in Mexico in I95 I as the regional federation of Latin American ICFTU members, the ORIT also collaborated with the Alliance for Progress. In the I960s, ORIT, headed by Arturo Jáuregui, a trade unionist with ties to the CIA and member of the AIFLD executive board, was tasked with enacting the AIFLD's agenda in each of the targeted Latin American countries. ${ }^{26}$ In Argentina, organizations belonging to the ORIT included the Confederation of Municipal Workers of the Argentine Republic, the General Confederation of Commercial Employees, and the National Bank Workers' Association, while in Brazil, ORIT affiliates included the National Industrial Workers' Confederation, the National Commercial Workers' Confederation, and the National Ground Transports Workers' Confederation. ${ }^{27}$ In this collaboration, ORIT and AIFLD specialized in organizing regional seminars intended to strengthen local unions. The courses generally addressed issues related to the world of trade unionism, such as trade union organizational structures, labor legislation, collective bargaining, trade union administration and finance, the union press, as well as many others. In addition to the AIFLD, other international union organizations such as the industry branch federations of the International Trade Secretariats (ITS), also dedicated themselves to sowing the seeds of "free and democratic unionism" across Latin America. $^{28}$

By the late 1970s, the AIFLD was offering labor education classes to approximately 23,000 workers across Latin America and the Caribbean annually and maintained offices in I 8 countries. By June 1978 , a total of 338,000 Latin American unionists had participated in the organization's in situ courses, where they learned about fundamental principles of trade unionism and organizational techniques, along with more complex issues

26. On the links between the CIA and ORIT, see Peter Gribbins, "Brazil and CIA", CounterSpy (April-May, 1979), pp. 4-23.

27. ORIT/ICFTU, "Report to the Sixth Continental Congress of ORIT", Mexico City, 2-6 February 1965, 17. The original names of these organizations are, for Argentina: Confederación de Trabajadores Municipales de la República Argentina, Confederación General de Empleados de Comercio e Asociación Bancaria; and for Brazil: Confederação Nacional dos Trabalhadores da Indústria, Confederação Nacional dos Trabalhadores do Comércio, and Confederação Nacional dos Trabalhadores em Transportes Terrestres.

28. Among the ITS members who were particularly active in Latin America were the International Transport Workers' Federation; International Miners' Federation; International Agricultural Workers' Federation; International Hotel and Restaurant Workers' Union; International Postal, Telephone, and Telegraph Workers' Organization; International Technical and Bureaucratic Workers' Federation; International Federation of Petroleum Workers' Unions; and International Federation of General Factory Workers' Unions. See: Robert J. Alexander and Eldon M. Parker, International Labor Organizations and Organized Labor in Latin America and Caribbean: A History (Santa Barbara, CA, 2009), p. 254. 
like trade union participation in economic development decision-making and interregional integration. The AIFLD also selected union leaders for intensive six-week programs at the George Meany Center in Silver Spring, Maryland.

Significantly, the AFL-CIO's education policy in the I960s and I970s ignored one important group of workers: women. Only in the mid-I970s did they begin to be chosen for scholarships and specialized courses. In the wake of International Women's Year and the UN's World Conference on Women in $1975,{ }^{29}$ the February 1976 edition of AIFLD's own journal, The AIFLD Report, highlighted a meeting for female union leaders, held in Asunción, Paraguay, part of the First International Women's Labor Leaders Congress. ${ }^{30}$ By 1977, sixty-nine women's groups from Latin America and the Caribbean enjoyed the full support of the AIFLD. ${ }^{3 \text { I }}$

The major part of the financial resources channeled through AIFLD, however, were not spent on education but social projects. For instance, nearly ninety per cent were dedicated to the construction of low-cost housing for workers. USAID, the second major funder of AIFLD, also allocated substantial means to this end. The Department of Social Projects, which was responsible for construction, had a partnership with Louis Berger and Associates, of Orange, New Jersey. In the late 1960s, accusations of corruption in Mexico led Berger to be investigated by Brazilian police. ${ }^{32}$ Still, construction continued, and by the end of 1978 , the AIFLD estimated that it had completed I 8,048 homes in thirteen countries, at a total cost of $\$ 77,3 \mathrm{I} 3,060$. Funds coming from USAID were, in some cases, funneled through the Regional Revolving Loan Fund (RRLF), which had been created in 1968 to manage funding for international social projects. According to the AIFLD, since the RRLF's creation in 1962, the organization had obtained $\$ 1,425,544$ from it to invest in

29. On International Women's Year, see Jocelyn Olcott, International Women's Year: The Greatest Consciousness-Raising Event in History (New York, 2017).

30. "Important International Women's Meeting", The AIFLD Report, I4:2 (April-May 1976), p. 2. The AIFLD Report was launched in 1963 and constitutes one of the major sources available documenting the organizations' the full scope of activities.

3I. See the following self-representation booklet published in 1980: AIFLD, American Institute for Free Labor Development: A Union to Union Program for the Americas (Washington, DC, I980), pp. 2 I-25.

32. According to a report by Brazil's notorious Department of Political and Social Order (Departamento Estadual de Ordem Política e Social), the police department in charge of the surveillance of all kinds of political and social movements, Berger was responsible for promoting projects of AIFLD interest in Latin America. His business had been expelled from Mexico, the report claimed, accused of corrupt dealings surrounding the construction of 3,100 residences in Mexico City. "Relatório sobre o Iadesil”, 4 August 1972, Arquivo Público do Estado de São Paulo (APESP), Departamento Estadual de Ordem Política e Social (DEOPS), Dossiê, 52-z-0, doc. 586I. 
social projects in Latin America and the Caribbean. ${ }^{33}$ The AIFLD oversaw the construction of the following number of houses, divided by country:

Table I. Number of houses built in low-cost housing projects financed through AIFLD, per country, I962-I978.

\begin{tabular}{lr}
\hline Country & Houses \\
\hline Argentina & 6,227 \\
Barbados & 3 \\
Brazil & 488 \\
Colombia & 2,106 \\
Costa Rica & 128 \\
Dominican Republic & 110 \\
Ecuador & 14 \\
Guyana & 362 \\
Honduras & 1,185 \\
Mexico & 3,104 \\
Peru & 2,979 \\
Uruguay & 425 \\
Venezuela & 920 \\
\hline
\end{tabular}

It is noteworthy that AIFLD investments in housing in Brazil were comparatively insignificant, only providing financing for 488 houses between 1962 and 1978 . If funding for housing alone is considered, Argentina was the largest recipient. Nevertheless, upon considering other investments like community centers, union headquarters, hospitals, and co-ops, Brazil received more AIFLD funding than any other country. In this total account of all funding, Argentina still came in second place, with means awarded for social assistance for workers, credit cooperatives, printing equipment, technical schools, and mutual aid funds. Other countries that "benefited" included Mexico, Peru, Colombia, Honduras, and Venezuela. ${ }^{34}$

\section{US LABOR EDUCATION IN BRAZIL: AIFLD'S ACTIVITIES IN DETAIL}

The AFL's foreign outreach to Brazil began after World War II. Between I945 and 1952, AFL trade unionists and government officials established contacts with local trade unionists, a challenging task as the aim was to look for a sector that was both non-communist and not too deeply affiliated with the corporatist tradition established during the Vargas era (I930-I945), 
or at least not too committed to its ideological tenets of populism and nationalism. In the I950s and early I960s, the AFL strengthened their collaborations with local trade unionists, hoping to train new leaders willing to implement so-called free and democratic trade unionism. ${ }^{35}$ To that end, the AIFLD financed exchange programs and regular visits to the United States. Their efforts enjoyed the support of the most anti-communist and conservative sectors of the Brazilian trade union movement, including the so-called pelegos, union leaders infamous for their willingness to ally themselves with whoever had power and money. ${ }^{36}$ Starting in 1962, the US government and AFL-CIO leaders openly supported the opponents of the pro-labor and nationalist President João Goulart (1961-1964). From 1962 to 1964, the US formed alliances with conservative civilian and military forces, which were in the process of orchestrating a plan to overthrow Goulart. ${ }^{37}$

There is even some evidence indicating that the AIFLD trained a select group of right-wing Brazilian union leaders who participated in an ancillary role in the conspiracy that led to the civilian-military coup that overthrew Goulart on I April 1964: In the months before, the AIFLD was training thirty-three trade unionists in the US who returned to Brazil in early I964 tasked with teaching "democratic" trade unionism in rural areas. Other groups of unionists, as Peter Gribbin has discovered, went to urban centers like Rio de Janeiro, São Paulo, and the port city of Santos. ${ }^{38}$ And several months after the coup, an interview given by William Doherty, representative of AFL-CIO International Affairs, publicized the involvement of US labor organizations in the coup. ${ }^{39}$ Doherty, however, may have overestimated the role of the US trade unionists in Goulart's ousting. Aside from the case of Rômulo Marinho, member of the Telegraph and Telephone Workers' Union of Guanabara, the activities of US-trained union leaders during those months so far remain shrouded in mystery. After taking classes in the United States, Marinho organized several anti-communist labor

35. Clifford Welch, "Labor Internationalism: US Involvement in Brazilian Unions, 1945-1965", Latin American Research Review, 30:2 (1995), pp. 62-89.

36. The term pelego is closely associated with the corporatist labor system established under Vargas. It refers to those conservative labor leaders who were central to the corporatist arrangement yet who did not buy too much into its ideological claims while acting compliantly under the direction of the federal Ministry of Labor, or who otherwise acted at the behest of politicians or entrepreneurs.

37. For the involvement of the US in the 1964 coup in Brazil see Phyllis Parker, Brazil and the Quiet Intervention, 1964 (Austin, TX, I979); Jan K. Black, "Lincoln Gordon and Brazil's Military Counterrevolution", in C.N. Ronning and A.P. Vannucci (eds), Ambassadors in Foreign Policy:

The Influences of Individuals on US-Latin American Policy (New York, 1987), pp. 95-I I 3.

38. Petter Gribbin, "Brazil and CIA".

39. Michael J. Sussman, AIFLD, US Trojan Horse in Latin America and the Caribbean (Washington, DC, 1983), p. 4. 
seminars aiming to prepare workers for an impending political crisis. ${ }^{40} \mathrm{Still}$, we know very little about the details of this operation. At any rate, "democratic" union leaders joined forces with other conservative sectors, such as military officers, right-wing political parties, students, and associations claiming to represent Catholic housewives, all of them eager to the celebrate the military intervention.

After 1964, the workers' movement was strongly repressed. Immediately after the coup, the new regime launched "Operation Clean-up", which resulted in an "intervention", i.e. a series of state measures against and purges in hundreds of rural and urban unions. ${ }^{41}$ Between March and April 1964, in the first weeks after the coup, the Ministry of Labor nominated 235 new union officials (called interventores) considered reliable by the regime. The Ministry was also granted the power to annul union elections and to veto the candidacy of any union leader, if it was deemed necessary. ${ }^{42}$ About seventy per cent of the unions with 5,000 members or more suffered this kind of state assault, and altogether, 536 organizations faced some form of "intervention" or repression between 1964 and 1970. According to the investigation conducted by the National Truth Commission (Comissão Nacional da Verdade $\mathrm{CNV}$ ), which, between $20 \mathrm{I} 2$ and 2014, investigated human rights violations committed during the military dictatorship, about 10,000 union leaders were purged, although there is still some disagreement regarding this data. ${ }^{43}$ The coup of 1964 seemed an important opportunity for US international union organizations to launch educational and welfare initiatives in unions across Brazil. The AIFLD hoped to contribute to the dismantling of the leftwing labor movement by forming a new generation of young unionists trained in the United States to replace the nationalist and Communist leaders. With the military in power, the number of training and union activities financed by AIFLD increased, developing the panoply of activities described above.

Meanwhile, the Brazilian military dictatorship, one of the longest in Latin America during the twentieth century, ending only in 1985 , was not a homogenous phenomenon throughout its existence. It changed several times some of its political and economic orientations and always pretended to observe a certain constitutional framework. These changes had important repercussions on the opportunities for unions in general and the conditions under which the American labor bodies acted. In 1968, after months of

40. These activities were reported in a Reader's Digest article: Eugene Methvin, "Labor's New Weapon for Democracy", Reader's Digest (October, i 966), p. 28.

4I. It should be added that the state prerogative to "intervene" into unions in all relevant matters was a legacy of the Vargas era.

42. Maria Helena Moreira Alves, State and Opposition in Military Brazil (Austin, TX, 1985), p. 70 .

43. See CNV's final report: Relatório Final do Grupo de Trabalho Ditadura e Repressão aos Trabalhadores e ao Movimento Sindical da Comissão Nacional da Verdade, 20I4, p. 59. 
anti-dictatorship mobilization that included large student demonstrations and labor strikes in important industrial cities, the regime's hardliners pushed for the enactment of Institutional Act number no. 5 (Ato Institucional Número Cinco - AI-5), issued on ${ }_{3} 3$ December. ${ }^{44}$ During this period, the regime intensified state repression and retreated somewhat from its strategic partnership with the United States (without ever ending it entirely). After General Artur da Costa e Silva became president in 1967, the relationship between Brazil and the United States became increasingly tense: Costa e Silva was seen as being linked to the least democratic sectors of the military high command, the so-called hardliners. While the hardliners were ardently anti-communist, they also had a strong nationalist streak and resented the high degree of economic dependence on the US fostered by the outgoing administration of General Humberto de Alencar Castelo Branco. The new Costa e Silva administration was more interested in obtaining loans to stimulate economic growth. His government, supported intellectually by developmentalist thought, which had considerable influence in Brazil at the time, sought a greater degree of independence from the US. Costa e Silva was not content with the funds offered by the US government through the Alliance for Progress. He and his supporters criticized the fact that most of the US funds were aimed at social assistance, especially to purchase basic necessities for the poor, such as food, medicine, and housing. The clash of interests provoked a gradual political distancing between the two governments, although US economic interests were maintained throughout the period.

The new political and economic project led by General Costa e Silva had a considerable impact on relations between Brazilian and US trade unions: After 1967, many conservative trade unionists, supporters of the military regime, began to question the interference of foreign trade unionists in local matters. They also questioned the effectiveness of the exchange program offered by the AIFLD, as well as the courses offered in the United States. The idea that the Americans were interfering too much in internal union affairs led in October 1967 to the opening of an inquiry in the Chamber of Deputies into the actions of foreign labor organizations in Brazil. ${ }^{45}$ In the wake of this investigation, the military government decided to monitor more carefully the AIFLD in Brazil. They expelled several American union leaders and urged the main Brazilian trade confederations to adopt a more anti-American posture. Unease with the strong influence of the US and, more specifically, with its interference in domestic politics, especially its criticisms of the regime, became

44. AI- 5 suspended constitutional guarantees and increased the dictatorial powers of the president. It also empowered the president to close Congress.

45. For more detailed information on this inquiry, see Larissa Rosa Corrêa, "Democracy and Freedom' in Brazilian Trade Unionism”, in Geert van Goethem and Robert Waters (eds), American Labor's Global Ambassadors: The International History of the AFL-CIO during the Cold War (New York, 2013), pp. 177-199. 
more widespread. Anti-Americanism became a trait that was no longer limited to leftist groups or the remnants of the corporatist nationalism of the Vargas era but also began to be identified with the authoritarian nationalism of the conservative civilian and military groups.

The Latin America visit of New York governor Nelson Rockefeller in 1969 is representative of the region's anti-American movement: Rockefeller, who maintained good relations with US-trained trade unionists, especially Serafino Romualdi, had been asked to lead a mission to Latin America and, based on what he observed there, make new policy suggestions to its governments. Months before his arrival in Brazil, Rockefeller had granted a \$75 million loan for Alliance for Progress initiatives through USAID. Nevertheless, he was met with a chilly reception and even protests in most countries, and the welcome in Brazil was not the warmest either. The Brazilian government still censored any negative reporting about his visit. ${ }^{46}$

In the early I970s, as the AIFLD encountered strong resistance in Brazil, it turned its efforts to the development of educational programs designed to promote "free and democratic unionism" in Argentina and Chile. ${ }^{47}$ However, the AIFLD maintained dialogue with the Brazilian government and continued channeling resources to the country, despite their awareness of the regime's acts of repression and of the impossibility of implementing the American model in a country whose labor relations were governed by corporatist legislation. Repression by the dictatorship was not only increasingly denounced; such accusations also gained a new weight with the rise of the "human rights" discourse and the corresponding notion of "human rights violations" in the I970s. In the face of these shifts, AFL-CIO representatives worried that their apathy might earn them criticism in Brazil and abroad. Notwithstanding accusations of torture, the government of Emílio Garrastazu Médici (1969-1974) presided over a period of "economic miracle", when growth exceeded, on average, ten per cent per year.

Brazil's growing economic clout rekindled the old friendship between Brazil and the US, American foreign policymakers believed that Brazil was on the cusp of becoming a regional leader and, in so doing, could project American influence in the region. This created a quandary for

46. On the visit itself, see for instance: "Dúvidas sobre a vinda de Rockefeller", Correio da Manhã, 3 June 1969, p. 3. On Rockefeller's relations with Brazil more generally, see Elizabeth A. Cobbs, The Rich Neighbor Policy: Rockefeller and Kaiser in Brazil (New Haven, CT, 1992).

47. On the activities of American organized labor in Chile and Argentina, see Angela Vergara, "Chilean Workers and the US Labor Movement: From Intervention to Solidarity, I950s-1970s", in Van Goethem and Waters, American Labor's Global Ambassadors, pp. 20I-2 I4; Pablo Pozzi, "El sindicalismo norteamericano en América Latina y en la Argentina. El AIFLD entre 196I-1976", Herramienta, Io (July, I999), available as a non-paginated html-version at: http://www.herramienta. com.ar/revista-herramienta-n-Io/el-sindicalismo-norteamericano-en-america-latina-y-en-la-argentinael-aifld; last accessed is October 2017. 
American trade union leaders, divided between the growing pressures of public opinion, which was goading them to take a position opposing the military's regimes human rights violations, and US political and economic interests. ${ }^{48}$ Thus, while AFL-CIO leaders publicly stated their wish to maintain a balanced view of the torture of political prisoners, they privately recognized, " $[\mathrm{w}] \mathrm{e}$ cannot ignore the facts contained in these reports [from Brazil], which we have the privilege of reading." 49

Why did the Alliance for Progress and AIFLD continue to invest so many resources in Brazil, even as its position had become complicated, first because of tensions mounting between the two countries' governments and then because of the increasing public criticism of the regime's repressive politics? To be sure, the country was still attractive to American business interests. But perhaps equally importantly, Brazil was also seen as a strategic site from which to monitor armed leftist groups in Argentina and Chile, above all during the government of Salvador Allende. We do know that the Brazilian dictatorship, despite the previous alienation vis-à-vis the US, allied with the Nixon administration (1969-1974) and provided technical and military support to coups in Bolivia, Uruguay, Chile, and, later, Argentina, even as it helped create a network of transnational repression in the Southern Cone, Operation Condor, which was tasked with exterminating leftist guerrillas. ${ }^{50}$ Brazil was a key ally for the US in the region's stabilization, and, despite all odds, American unionism continued to collaborate closely with US foreign policy in the fight against what was considered to be a uniform threat of "communism".

\section{AMERICAN “FREE UNIONISM” IN ARGENTINA}

Like in Brazil, the relationship between American trade unionism and the Argentine labor movement began in the immediate post-war years, through contacts made by Serafino Romualdi. In Argentina, however, as Pablo A. Pozzi has pointed out, between 1946 and 1960, the AFL-CIO labeled Peronist union leaders as "fascists". ${ }^{5 I}$ Basualdo's study of the relationship between the ICFTU, ORIT, and Argentine unions similarly paints a picture of frequent conflict, particularly during the rule of Perón, between I 946 and

48. On opposition to the Brazilian military dictatorship in the US, see James Green, We Cannot Remain in Silent: Opposition to the Brazilian Military Dictatorship in the United States (Durham, NC, 2010).

49. Andrew McLellan, AFL-CIO inter-American representative, to Alan Silberman, labor officer at the US embassy, 20 January 1970, George Meany Memorial AFL-CIO Archive (University of Maryland, College Park, MD), RG I 8, series 4, box I6.

50. J. Patrice McSherry, Predatory States: Operation Condor and Covert War in Latin America (Lanham, MD, 2005).

5. Pozzi, "El sindicalismo norteamericano en América Latina”. 
I $955 .{ }^{52}$ However, Perón's fall in I955 and the Cuban Revolution I959 were game changers, and American authorities, instead of treating the Peronist labor movement as a homogenous group, began differentiating between what they considered as "communists" and "anti-imperialist nationalists", i.e. a more militant and left-leaning current within Peronism and a less leftwing one, which the Americans hoped to win for their cause. ${ }^{53}$

After 196I, Romualdi broadened his contacts among Argentine union leaders, establishing a fruitful alliance with specific Peronist sectors, especially Augusto Vandor (1923-1969), who became one of his primary interlocutors until mid-1960s. These relationships were also fundamental for the AIFLD in its efforts to gain a foothold in Argentina after its foundation in 1962. The increasingly cozy relations between the AIFLD and the largest Argentine labor confederation, the General Labor Confederation (Confederación General del Trabajo - CGT) enabled the implementation of a labor education project, which the AIFLD had wanted to launch in Argentina already for some time. As Gabriela Scodeller has shown, labor education was a field of dense competition and site for major conflicts among the various factions of the Argentine labor movement. ${ }^{54}$ Union education was seen as a privileged medium for efforts to promote the political-ideological agenda of each current and it was an important step forward for AIFLD to gain access to this field via the CGT.

Throughout the I960s, the AIFLD developed a complex and controversial relationship with the Argentine anti-communist trade unions through both social programs and a series of courses intended to train "authentic" leaders. The goal was to halt the radicalization unleashed by the local influence of different left-wing currents (erroneously) subsumed under the label of "communism" and Peronism on the workers' movement." In Brazil, things were no different; in both countries, the AIFLD saw shifting alliances and fallings out with local union leaders, but the constant was that the local leaders

52. Victoria Basualdo, "El sindicalismo 'libre' y el movimento sindical argentino desde mediados de los años '40 a mediados de los años' 50”, Anuario IEHS, 28 (2013), pp. 279-294.

53. Pozzi, "El sindicalismo norteamericano en América Latina”. It should be added that - despite the Americans major concern with "communism" and "communist infiltration" - by the I950s, the Argentine Communist Party (PCA) had lost most of its previous allegiance within the local labor movement. "Communism" should thus be taken as an imprecise signifier for a broad spectrum of different left-wing currents.

54. Gabriela Scodeller, "El Instituto de Capacitación y Formación Social Sindical. Una experiencia de formación politico-sindical en un contexto de intensa conflictividad social (Argentina, 1963-1965)", Revista Mundos do Trabalho, 5:9 (2013), pp. 239-258.

55. Juan Alberto Bozza, "Cooperación y cooptación. Agencias norteamericanas sobre el sindicalismo peronista en los sesenta", paper presented at the Segundo Congreso de Estudios sobre el Peronismo (1943-1976), 4-6 November 2010, at the Universidad Nacional de Tres de Febrero, Sede Caseros II (Provincia de Buenos Aires). See also Juan Alberto Bozza, "Trabajo silencioso. Agencias anticomunistas en el sindicalismo latinoamericano durante la Guerra Fría”, Conflicto Social, 2:2 (2009), pp. 49-75. 
with whom the American organization dealt were usually of a non-militant, non-bottom-up type whose vision of defending workers' interests was striking deals with employers and whoever had political power.

In the social arena, it is noteworthy how much the organization spent on "Operation AFL-CIO", which planned to build hundreds of homes for Argentine workers with a budget of $\$ I 7$ million. This amount shows just how important Argentina was to the AFL-CIO and, according to Pozzi, it consolidated the AIFLD's position in the country. By 1965, on the eve of the coup that overthrew president Arturo Illia (1963-1966), the AIFLD had two main goals in Argentina: I) to deepen the divisions between Peronists and the left within the labor movement (which, as many Peronist labor activists increasingly leaned to the left, meant supporting the more right-wing currents within Peronism), through training and promoting "democratic" leadership, and 2) to introduce the American model of "business unionism" through labor education courses and social programs. ${ }^{56}$

Most AIFLD courses were conducted for small groups of workers, like the lumberjacks near the forest of Santiago del Estero, or farm workers in San Juan and villages in the Pampas interested in new agricultural techniques. Intensive "second-level" regional seminars lasted fifteeen days and were held in the late I960s in cities like Comodoro, Rivadavia, Jujuy, Ingenio, Ledesma, Córdoba, and Mendoza. They were targeted at a vast array of professions: textiles and clothing, hospitals, entertainment, the maritime service, wine making, food service, petroleum, electricity, glass, leather, banking, insurance, government employment, postal and telephone services, transportation, commerce, printing, metal working, and auto making. ${ }^{57}$

In I968, the AIFLD further expanded its operations in Argentina with an office in Córdoba, one of the country's industrial centers and site of intense mobilization for both the labor and student movements, which would explode the following year into the Cordobazo. ${ }^{8}$ The AIFLD Report, the organization's periodical, in 1969 celebrated the great impact its social and educational programs had had on Argentina. Like in Brazil, these programs were carried out mainly in smaller cities or rural areas, places whose unions had little or no influence in the organized labor movement nationally. For example, the Report highlighted a seminar for journalists held in the northwestern city of Tucumán. It was co-sponsored by the local branch of

56. Pozzi, "El sindicalismo norteamericano en América Latina”.

57. Charles Wheeler, "AIFLD's Programs in Argentina Underscore Friendship between Hemispheric Unionists”, The AIFLD Report, 7: 9 (1969), pp. 5-6.

58. The goal of the new office in Córdoba was to support Alejo Simó of the Metal Workers' Union of Córdoda (Unión Obrera Metalúrgica - UOM) in his power struggle with Agustín Tosco, the legendary militant union leader of Córdoba's section of the Electric Energy Workers' Union (Federación Argentina de Trabajadores de Luz y Fuerza - FATLyF) and the CGT. Pozzi, "El sindicalismo norteamericano en América Latina". 
the Press Association and Journalists' Federation of Argentina (Federación Argentina de Periodistas - FAP); the main participants were university professors and members of the local press. ${ }^{59}$ But these locations, which in the Argentinian context were rather peripheral, and the social composition of these courses indicate how difficult it was for AIFLD to intervene in a country where the labor movement was disputed mainly among the left and left-leaning Peronists. Also in I 968, the AIFLD financed the fifth version of a national labor education course attended by fifty students from thirty local unions around La Plata, Pergamino, and Mercedes.

The AIFLD curriculum officially consisted of sociology, human relations, and public speaking. In practice, it emphasized economics, collective bargaining, job evaluation, productivity, and cooperativism. By the end of the I960s, the organization had thirteen social projects underway in the regions of Buenos Aires, La Plata, Bahia Blanca, and Santa Fé. In I969, the AIFLD provided loans of $\$ 13.5$ and $\$ 4$ million for private investors to develop a workers' housing initiative, backed by USAID and the National Mortgage Bank of Argentina. ${ }^{60}$

As the I960s drew to a close, the AIFLD evaluated its track record in Argentina positively: With the country's labor movement largely held down by the right-wing dictator General Juan Carlos Onganía, the AIFLD was free to carry out its program as it saw fit. Charles Wheeler, director of social projects since 1965, had been fairly successful in his task of uniting all the "democratic" unions of the Argentine labor movement, which, in practice, meant leaders who were both anti-communist and anti-Peronist. ${ }^{6 \mathrm{I}}$ In spite of the resistance of both groups to "free" unionism, the extent to which AIFLD quickly came to influence labor in the country as a whole, particularly through its alliance with groups tied to Augusto Vandor, should not be underestimated. A significant proportion of union leaders who were able to develop a more stable activity during the last two Argentine military dictatorships (I966-I973 and I976-I983) were trained in programs in the US. They came from unions like the Postal and Telecommunication Workers and Employees' Federation, the Confederation of Municipal Workers of the Argentine Republic, the Argentine Light and Power Workers' Federation, the Bank Workers' Association, the Argentine Confederation of Transport Workers, the Railroad Union, and The [train driver's] Fraternity. ${ }^{62}$

59. Anon. "Journalists hold Labor Seminar, Tucumán, Argentina”, The AIFLD Report, 7:I (1969), p. 3.

60. Charles Wheeler, “AIFLD’s programs in Argentina Underscore Friendship...”, pp. 5-6.

6r. Ibid., pp. 4-5.

62. The original names are as follows: Federación de Obreros y Empleados de Correos y Telecomunicaciones, Unión de Obreros y Empleados Municipales, Federación Argentina de Trabajadores de Luz y Fuerza, Asociación Bancaria, Confederación Argentina de Trabajadores del Transporte, Unión Ferroviaria, and La Fraternidad. 
Members of the CGT, who denounced "imperialist" infiltration in their ranks in the late I960s, estimated that close to 80,000 union members had taken the AIFLD's labor education courses. Many collaborated with the Onganía dictatorship despite its openly anti-labor policies and were on friendly terms with the local branches of American corporations that helped fund the AIFLD. As Juan Alberto Bozza has argued, "[i]n the I960s, challenged at the grassroots level by combative associations and activists, the most vigorous internal currents within Peronism, the 'Vandorists' and 'participationists', revived their latent McCarthyism." ${ }^{33}$ Among the allies of the American unions were Juan Racchini, of the Carbonated Water Workers' Union (Sindicato Unico de Trabajadores de la Industria de Aguas Gaseosas de la Argentina - SUTIAGA), and the Insurance Union, led by José Báez, a "technocrat" who had received training in AIFLD courses. And as the conflicts within the Argentine labor movement intensified, groups like the Argentine Light and Power Workers' Federation (Federación Argentina de Trabajadores de Luz y Fuerza - FATLyF), headed by Juan José Taccone, deepened their ties with the AIFLD.

AIFLD publications were full of optimism, often masking a much less glowing reality. The general mistrust by Argentine unionists and workers never abated, and the ill-fatedness of some of AIFLDs projects further undermined its credibility. For instance, the project aimed at building housing for workers was a failure and became the object of severe criticism, not only in Argentina, but also in Brazil. For example, as Pozzi has found, although the homes were budgeted at $\$ 3,200$, their final cost varied between $\$ 6,000$ and $\$$ I I, 500 . Something that was supposed to be a grand gesture of support for Argentine workers ended in mistrust and conflict, not only due to the cost overruns, which suggested malfeasance and self-enrichment by union officials, but also due to the relatively limited benefits that a few thousand houses had for workers as a class. ${ }^{64}$

The AIFLD was surprised by the most important workers' uprising in South America in the I960s, the Cordobazo, ${ }^{65}$ and the subsequent labor conflicts that toppled Onganía in 1970 . The heightening of political tension, along with fear of what it saw as "communist" infiltration in the Peronist

63. Bozza, "Trabajo silencioso", p. 68.

64. Pozzi, "El sindicalismo norteamericano en América Latina".

65. The Cordobazo was a general strike and uprising in Córdoba, Argentina's second biggest city, in May 1969. It saw the city's industrial workers (especially from the car industry) as well as radicalized students and major parts of the general population enter into strike and challenge the dictatorship's authorities. It was greatly shaped by the long tradition of militant, left-wing Peronist unionism, embodied by Augustín Tosco, and a small but significant array of radical leftist groups that had emerged in the wake of the Cuban Revolution. See James P. Brennan and Mónica Gordillo, "Working Class Protest, Popular Revolt, and Urban Insurrection in Argentina: The I969 Cordobazo", Journal of Social History, 27: 3 (1994), pp. 477-498. Also see the more recent: James P. Brennan and Mónica B Gordillo, Córdoba rebelde. El cordobazo, el clasismo y la movilización social (La Plata, 2008). 
labor movement and the strong reaction of the working class to Onganía's anti-labor policies, led the AIFLD to modify its internal structure and programs. The growth of guerrilla groups and the assassination of AIFLD ally August Vandor in 1969 (not accidentally by a competing left-wing Peronist faction) only worsened the situation. Wheeler was replaced as director of social projects by James Holway, a lawyer and former American consul-general in Brazil in 1960-1964, who maintained strong ties to the State Department. Holway closed the Córdoba office and cut the housing programs, opting instead to invest further in labor education and in worker credit cooperatives. ${ }^{66}$

The restoration of democracy in 1973 and the powerful opposition of Argentine labor to AIFLD caused the organization to practically close its doors by 1974. But the new coup of 1976 would create a more amenable climate, once again making clear the intimate relationship between the AIFLD and Latin American authoritarian regimes. After all, the temporary interruption of its activities hardly meant that the AIFLD had abandoned Argentina. The organization had spent eleven years building its influence and developing a network of contacts, and these were reactivated after the coup of 1976 .

The dictatorship established under Jorge Videla in 1976, however, ushered in a period of state terrorism with massive repression targeting activists of all currents and using forced disappearances in a systematic way to physically exterminate any kind of social movement. Facing this situation, which also saw AIFLD contacts under attack, as well as under the influence of the international "human-rights-turn", AIFLD changed course. Now, its contacts would start to function as a base of support and financing for important union leaders from the leftist CGT, long-time opponents of the AIFLD. American labor assumed a new role in Argentina and, like the International Labor Organization (ILO), which had an important role in denouncing the regime's human rights violations against Argentine workers and union leaders and its termination of union autonomy, the AFL-CIO also sought to apply pressure. ${ }^{67}$ Thus, even as the organization once again consolidated its position as one of the most important influences on the Argentine labor movement, it also began to oppose and even internationally criticize the regime's serious human rights violations. Soon after the military seized power, George Meany, president of the AFL-CIO, sent Videla a telegram asking for the release of imprisoned unionists, the return of union autonomy, and the re-establishment of civil and workers' rights. ${ }^{68}$

66. Pozzi, "El sindicalismo norteamericano en América Latina".

67. Victoria Basualdo, "The ILO and the Argentine Dictatorship (1976-1983)", in Jasmien van Daele et al. (eds), ILO Histories: Essays on the International Labour Organization and Its Impact on the World During the Twentieth Century (Bern, 2010), pp. 40I-42 I.

68. Anon., "US Labor Concerned with Situation in Argentina", The AIFLD Report, I 4:3 (1976), p. 9. 
The ORIT equally expressed its disapproval of the junta's repression. Almost one month after the coup, members of the group visited Buenos Aires to take stock of the situation of Argentine workers and converse with union leaders who had not been imprisoned. The ORIT also sent various telegrams to the military government expressing its disapproval "of the strong hand tactics used against labor leaders and their organizations" ${ }^{69}$ In mid-1977, the AFL-CIO Executive Council announced its enthusiastic endorsement of President Jimmy Carter's (1977-198I) decision to make human rights the cornerstone of American foreign policy. Consequently, the AFL-CIO expressed its concern with the political situation in South Africa, Chile, Uganda, and, of course, the Soviet Union. Argentina was not cited, whether intentionally or not. Thus, the American union stated a position that was meant to represent a turn of position, yet which also aptly captured its decades-long interventionist stance towards Latin America: "There are no longer any purely internal affairs." 70

\section{RETHINKING US-SOUTHERN CONE LABOR RELATIONS}

The actions of AIFLD and other international bodies of American labor during the I960s and I970s have been the object of controversy early on. One of the most influential scholars on labor in Latin America at the time, Robert Alexander, both a nuanced observer of the subcontinent's realities and a staunch defender of "free unionism", exculpated AIFLD's role by arguing that it faced the opposition of a series of undemocratic governments hostile to "free" trade unionism. In these situations, he said, the organization had to decide whether to continue its activities or leave the country. In places where hostility was limited to certain sectors of the economy, it was possible for the AIFLD to simply shift its focus to other sectors. In dictatorial countries where it was not possible to promote "free" unionism in any area of the economy, it still might be possible to maintain educational projects and wait for political change. Finally, in countries where all union activity was repressed by authoritarian regimes, Alexander argued together with Eldon Parker that the AIFLD, through its ties to USAID and the American government, could still "provide some kind of protective covering for unionists who were trying to offer some resistance to the complete suppression of a free labor movement" ${ }^{71}$ Although Alexander had little to say about the cozy relationship the AIFLD long maintained with dictatorial regimes, especially in Latin America, he did mention that the organization was forced to deal with critics who considered it an accomplice of authoritarians and tyrants.

69. Ibid.

70. Anon., "AFL-CIO Executive Council Endorses President Carter's Human Rights", The AIFLD Report, I 5:2 (1977), p. 3.

7I. Alexander and Parker, International Labor Organizations and Organized Labor, p. 277. 
A number of other scholars recognized early on how closely the AFL-CIO tied itself to Latin American military dictatorships. ${ }^{72}$ Yet, the finer grained strategies employed and difficulties endured by the United States' largest labor union and its Latin American counterparts have remained largely in the dark. Even the inspiring set of more recent works, which have examined the role of the AFL-CIO in the region in more detail, have not sufficiently analyzed its effects on local workers and union members, whose interests were shaped by the political, social, and economic transformations experienced by their own countries, and whose relationships with US organized labor could shift suddenly and unexpectedly. ${ }^{73}$ Many issues and dimensions remain yet to be explored here: For instance, even if it is possible to give a quite detailed picture about AIFLD's educational activities we do not know yet how and to what extent union leaders incorporated the things they had learned in their courses on "free" unionism. Similarly, there remains much to be discovered about how workers and their unions in Brazil and Argentina reacted in the face of the ambiguous positions - characterized by their simultaneous collaboration with and opposition to the regimes - that the AIFLD took later on at the most repressive moments of dictatorial rule.

This article has aimed to start a scholarly conversation about these issues by suggesting that there is a lot to gain from returning to a systematic comparison of American union activities in different countries. Choosing two main cases from the region, Brazil and Argentina, which in the period studied were most of the time ruled by military dictatorships, it has pointed to a series of similarities and some significant differences. Following the ongoing debates in the study of international organizations, the Cold War, and the relations between the US and Latin America, I have contended that the interaction between international bodies of American unionism and local unionists in Brazil and Argentina was much more intermingled and contradictory than envisaged in such notions as "cooperation", "co-optation", "domination", or "autonomy".

I began this article with three questions. The first asked what kind of unions were involved in the AFL-CIO's labor education program: The evidence indicates that these tended to be the least influential unions, whose leaders carried little weight in the more militant national movement dominated by nationalists and leftists. In other words, in both countries it was

72. Fred Hirsch, An Analysis of the AFL-CIO Role in Latin America, or, Under the Covers with the CIA (San Jose, CA, 1974); Hobart A. Spalding, "US and Latin American Labor: The Dynamics of Imperialist Control", Latin American Perspectives, 3: I (1976), pp. 45-69; Michael J. Sussman, AIFLD, US Trojan Horse in Latin America and the Caribbean.

73. Bozza, "Trabajo silencioso"; Pozzi, "El sindicalismo norteamericano en América Latina"; Scodeller, "El Instituto de Capacitación y Formación Social Sindical”; Basualdo, "El movimiento sindical argentino y sus relaciones internacionales". 
difficult for the American actors to find an actual interlocutor. Most of the trade unionists considered "democratic" due to their alignment with American unionism were at the margins of the Argentine and Brazilian labor movements. In Brazil, the AIFLD's social and educational projects ultimately did not succeed in altering the increasing support enjoyed by the communists and nationalists in the unions. The situation was similar in Argentina during democratic periods, or when the Peronists were on the rise. Both countries had been marked by a long tradition of corporatist arrangements between the state, the unions, and the employers (trabalhismo under Vargas in Brazil, Peronism in Argentina), by a heightened social conflictivity, and by the coming to power of military regimes. There is clear evidence that AIFLD transferred strategies it had tried and tested in Brazil during the first half of the r960s to Argentina where its engagement intensified only from the mid-I960s on. In both countries, it was most successful in attracting unionists who were both part of the corporatist arrangement, yet had no (or less) allegiance to a corporatist ideology and nationalism. In transferring their strategies, however, AIFLD had to struggle with two significant differences between the two countries: First, the support for Peronism among unions and the currency of an outspokenly left-wing Peronism in Argentina went beyond the corporatist legacy in Brazil and made it more difficult to find appropriate interlocutors. Second, while the influence of "communism" had to be exaggerated already in the case of Brazil (where the communists had some notable currency among more militant unions), the Argentine realities saw a broad array of left-wing currents within and outside of the labor movement, numerous of them claiming a revolutionary orientation and sympathizing with Cuba, yet the communists proper by the I960s had lost most of its support and were a comparatively marginal group.

It is undeniable, however, that the supposedly "democratic" trade unionists encountered increasing opportunities during the periods of political instability before and after the coups in Brazil (I964) and Argentina (I966 and 1976). As Bozza points out, American trade unionism, acting through the AIFLD, specialized in exploiting situations of "[military] intervention or destabilization of leftist and progressive governments". ${ }^{4}$ Indeed, the evidence shows that the AIFLD ramped up its investments and activities during the periods that immediately preceded the military coups and during the dictatorships themselves. The investments in labor education courses proved useful for advancing American labor's anti-communist agenda when those who had participated in such courses took up leadership positions in their unions after their leftist or nationalist colleagues, now considered enemies of the state, had been removed. 
The second interest of this article was to analyze and compare the kind of concrete activities developed in Brazil and Argentina. In both countries, the AIFLD invested millions of dollars in two types of projects: training of union leaders and social projects intended to improve the living conditions of workers committed to "free" unionism. However, in Argentina, the AIFLD spent liberally on housing for workers, while in Brazil, assistance took more the form of loans, construction of union headquarters, hospitals, and credit cooperatives. In fact, when compared with AIFLD expenditures in other countries, Argentina received the highest funding for housing of any country in Latin America. One possible explanation is that the Americans considered the Argentine labor movement to already be highly organized, and thus focused their efforts not on strengthening the unions themselves, but rather on conquering the "hearts and minds" through initiatives more directly targeted at workers. Beneficiaries of AIFLD housing were to be carefully tracked so that they could be called upon when needed to collaborate with "free" trade unionism. ${ }^{75}$

As to the educational programs and their impact, it seems clear that in both countries AIFLD offered abundant incentives to workers and trade unionists who were both anti-communist and against a left-wing interpretation of the corporatist legacy of either Peronism or Vargas: trips to US schools for specialized courses, events at the US embassy, opportunities for favors or loans for local unions, often enabling these individuals to gain a higher position. In exchange, AIFLD beneficiaries served as part of a wide network of contacts that not only included union officials at different levels, but also representatives of laborist institutions like the labor court system and Labor Ministry, officials at the American embassy, national and multinational business leaders, journalists, and academics. This network, in turn, enabled the US to gather and report information on the labor movement in both countries.

As it formulated its Cold War strategy for Latin America and the policy orientations for such international actors as AIFLD, the AFL-CIO was shaped by its experiences in Brazil immediately before and after the coup of 1964. Undeniably, by the mid-r 960 s the American unionists and authorities were aware of the consequences of military regimes that were installed against nationalist and leftist Latin American governments as well as of the implications of supporting such regimes. Through their complicity, or even outright collaboration, more than twenty years later with the 1976 Argentine coup, the people that had dominated the AFL-CIO for more than four decades showed once again that their overriding foreign labor policy concern was anti-communism.

Yet, the close relationships that the AFL-CIO built with authoritarian regimes created a quandary and resulted in countervailing dynamics which 
complicate any assessment of its actions: At the same time that the organization depended on conservative governments to help them increase their reach and influence upon local labor movements, the AFL-CIO started to commit meaningful acts of solidarity with and assistance for Latin American workers at the very moment when the regimes were at their most repressive. Becoming part of the human rights-turn in international politics, the American unions shifted from supporting these military dictatorships to criticizing them. It was in this way, at least in Brazil and Argentina, that the American labor movement at first supported military coups, only to later condemn the dictatorships and denounce their attacks on union autonomy.

Translation: Bryan Pitts 